\title{
Saudi EFL High School Learners' Attitude Toward Learning English
}

\author{
Majed Ghazai Alotaibi \\ Ministry of education, Taif district, Saudi Arabia
}

\begin{abstract}
Attitude is an important factor that influences evolving English language learning and determines whether the learner will embrace learning or not. This study aimed at investigating the attitudes of high school learners in Saudi Arabia toward English learning. To achieve this, the descriptive method was used. To collect the data, a 24-item attitude questionnaire was administered to measure learners' attitudes. Participants consisted of 118 randomly chosen learners in their third year of high school. The results showed that Saudi English language learners had a positive attitude toward learning English. The findings suggested that teachers should create a pleasant classroom atmosphere and design experiences that match the learners' interests. The study also recommended that other studies should examine the attitude of learners toward learning specific skills, such as writing or reading stories, as well as determine the challenges faced during English learning.
\end{abstract}

Keywords: Attitude, English as a foreign language (EFL) learners, Language learning.

DOI: $10.7176 / \mathrm{JEP} / 11-20-10$

Publication date:July $31^{\text {st }} 2020$

\section{1-Introduction}

Attitude is a crucial field in social psychology and education studies. Therefore, it is investigated in second language (SL) learning to illustrate why there are differences in SL attainment among learners (Tsunemoto \& McDonough, 2020). It is described as a set of beliefs that a student holds toward the second or foreign language, such as whether it is interesting, important or boring (Brown, 2007). SL learning is a social and psychological phenomenon, so it is essential to consider the conditions under which it takes place, one of these being attitude, which has a strong influence on language learning (Khalid, 2016). There are several reasons for studying attitude toward English language: first, shaping the levels of proficiency in the SL learning is determined by the attitude; second, to assess whether the situation of learning is good or bad and how cultural context can influence language learning (McKenzie, 2010); finally, positive attitudes can help learners to engage in active efforts to develop their ability in language learning (Cherciov, 2012).

There is extensive research on the attitudes of learners toward learning English. For example, some studies have investigated the attitude of university students toward English learning (Khan, 2016; Al samadani \& Ibnian, 2015), in which educators were advised to design activities and implement strategies to motivate the students and foster them to develop their attitudes toward learning English as a foreign language (EFL). In addition, a study on high school learners in the United Arab Emirates (UAE) suggested that they want a teacher who can encourage them to speak more in the classroom, teach them how to use language outside the classroom, and create an informal environment where they can enjoy learning (Alnourasi, 2013).

The majority of previous studies have focused on university students' attitude toward learning English, however, there is a need to study the attitudes of high school learners. The main aim of this study is to examine the attitudes of Saudi high school learners toward English language learning.

\section{2-Literature review}

\section{2-1 Attitude toward English Language Learning}

There are several definitions of attitude, such as, "it is a predisposition to respond in a favorable or unfavorable manner with respect to a given attitude object" (Schultz \& Oskamp, 2005 p.9). In language leaning, Ahmad (2015) describes attitude as a set of feelings that are good, bad or neutral. These feelings can nurture or hinder the learning process effectively regarding language use and its status in the society. According to McKenzie (2010), attitudes are not directly observable but can only be inferred from respondents' introspection. There are three components that can describe the structure of attitudes: the affective, the conative, and the cognitive (Dittmar, 1976). The affective component refers to emotional reactions of persons, the cognitive to an individual's belief and knowledge about attitude object, and the conative involves the tendency to act in a certain way toward the object (Cherciov, 2012; McLeod, 2018). Despite interference between attitudes and other terms such as values, opinions and beliefs, attitude is an evaluation of an object of thought, comprising objects as things, people, and ideas (Bohner \& Dickle, 2011).

A positive attitude toward foreign language (FL) learning has been found to increase learners' performance. For example, Dewaele \&Dewaele (2018) used correlation analyses to determine the strongest predictors of willingness to communicate FL in London high schools. The result was that learners who had more positive 
attitudes toward the FL were also much more likely to communicate successfully in the FL. Similar conclusions were reached by a study by Al samadani \& Ibnian (2015) on Umm Al-Qura University in Saudi Arabia. Measured through questionnaires, it showed that there was a strong positive correlation between those students with a high grade point average (GPA) and high levels of positive attitude toward learning English. In addition, students' attitudes are considered an important factor in relation to FL acquisition, which may be tied to their motivation and behavior (Tsunemoto and Mc Donough, 2020).

Depending on the importance of a strong relationship between learners' attitudes and their ability to practice speaking in the English language, many studies have investigated EFL students' attitude (Al-Sobhi, Rashid \& Abdullah, 2018; Jaliyya \& Idrus , 2017; Ibnian, 2017; Al samadani \& Ibnian, 2015; Alkaff, 2013; Alnourasi, 2013), and found a positive attitude toward English language learning. For instance, Al Noursi (2013) conducted a study to identify the attitudes of the learners at the UAE Applied Technology High School toward English language learning. Data were collected from 196 learners using a questionnaire. The findings revealed that most of the respondents of the study had positive attitudes toward English Language learning.

In the same vein, Alkaff (2013) studied the attitudes of students at King Abdulaziz University in Saudi Arabia toward English learning. Data were collected from 47 female students using a questionnaire. The findings of the study showed that most students had positive attitudes toward learning English and that they sought to improve and to use the language even though there were a lot of demands on their time and few opportunities to practice their English.

Later, Al-Sobhi, Rashid \& Abdullah (2018) investigated the attitudes of Arab high school learners toward English language learning in Malaysia, with a questionnaire being administered to 70 Arab learners studying English as a second language (ESL). The study showed that the learners had a high positive attitude toward English language learning.

However, various studies have revealed the negative attitude of learners (Zulkefly \& Razali, 2019; Khan, 2016; Ahmed, 2015; Aouachria, 2015; Abidin et al., 2012). For example, Zulkefly \& Razali (2019) investigated rural Malaysian high school learners' attitudes toward learning ESL. Employing a case study approach, four learners from two different grade levels in a rural high school were purposively chosen. The results revealed that some learners had negative attitudes toward learning the English language and suggested that there were two critical factors affecting the learners' attitudes toward the learning of English. First, lessons did not cater to learners' proficiency levels and interests, and second, the reactions of learners to negative and positive experiences.

In the Arab community, where English is a foreign language, Aouachria (2015) examined middle school learners' attitudes toward learning EFL at Batna city in Algeria. The sample consists of 301 learners who were subjected to a questionnaire. The findings of the study showed that the learners' attitudes toward English language learning were negative.

In addition, Khan (2016) conducted a study to determine the attitudes of Saudi students at Jeddah Community College toward learning English. The findings revealed that the students generally do not have a positive attitude toward learning English. The study also revealed that a poor background in English, the fear of making grammatical mistakes, and lack of confidence and peer support lead to lower performance.

According to the literature review there were contradictions in the findings about learners' attitudes toward English language learning. Moreover, the majority of the previous research has been applied in universities, except for a few studies conducted in intermediate and high schools. Despite understanding that high school learners' attitudes can help teachers to develop instructional practices, up to now there have been no attempts to examine the attitudes of high school learners toward English language learning in Saudi Arabia. Consequently, the current study tries to answer the following question: What are the attitudes of high school learners toward English language learning?

\section{3-Method}

\section{3-1 Participants}

The participants were 118 English L2 high school learners in Taif, Saudi Arabia. Their first language was Arabic, they were all male and they ranged in age from 16 to 18 years.

\section{3-2 Material}

A 24-item Likert-scale questionnaire was conducted by the researcher to elicit the EFL learners' attitudes toward English language learning. The material was designed according to instruments used in prior research (Alsamadani \& Ibnian, 2015; Alnourasi, 2013). The participants were asked to choose the degree of agreement on a three point Likert scale (3 (agree), 2 (neutral), 3 (disagree)). The Likert scale was interpreted by three values: negative attitude 1.00 to 1.66 , positive attitude 1.67 to 2.33 . strong positive attitude 2.34 to 3.00 .

3-2-1 Validity and Reliability

To establish the content validity, the instrument was reviewed by a panel of six experts in English language 
teaching methods, so some items were modified, and some were added according to the jury members' comments and suggestions.

In respect of reliability, the questionnaire was administered to a sample of 25 learners other than the sample of the study. The alpha Cronbach coefficient was used to measure the internal consistency. The reliability for attitude scale was 0.93 , which is good for the current study purpose.

\section{3-3 Procedures}

After validity and reliability had been verified, the researcher distributed the closed-ended questionnaire to the participants, who were randomly selected from EFL learners in the third grade of high school in Taif, Saudi Arabia, then they were given a preliminary clarification of the purpose of the research before the data were collected. Next, the respondents were asked to complete the questionnaire in one sitting during the second semester of the academic year 2019/2020. Next, the data were collected and coded in tables. Finally, data were analyzed using means and standard deviation, results were presented, and discussion was held.

\section{4-Result}

To answer the study question "What are the attitudes of high school learners toward English language learning?" the researcher analyzed the questionnaire using means and standard deviation, as shown in Table 1 below.

Table 1. Means and standard deviation of the participants' responses to the attitude questionnaire

\begin{tabular}{|c|c|c|c|}
\hline Items & Mean & $\begin{array}{c}\text { Std. } \\
\text { Deviation }\end{array}$ & $\begin{array}{l}\text { Level } \\
\text { attitude }\end{array}$ \\
\hline 1- I prefer to focus on English rather than other subjects. & 1.85 & .85 & Positive \\
\hline 2-Learning English is interesting. & 2.07 & .70 & Positive \\
\hline 3- I study English to pass the exam & 2.02 & .74 & Positive \\
\hline 4- Mastering English will help me get a suitable job in the future. & 2.51 & .62 & Strong positive \\
\hline 5- Learning English is easy. & 1.73 & .72 & Positive \\
\hline 6- Learning English is not important. & 2.17 & .76 & Positive \\
\hline 7- I always practice English outside school. & 2.44 & .85 & Strong positive \\
\hline 8- I feel proud when I speak in English. & 2.40 & .76 & Strong positive \\
\hline 9- I am going to learn English in the future. & 2.26 & .80 & Positive \\
\hline 10- I love reading English stories & 1.64 & .73 & Negative \\
\hline $\begin{array}{l}\text { 11-I get nervous when my English teacher asks me to write a } \\
\text { paragraph. }\end{array}$ & 1.97 & .77 & Positive \\
\hline 12- I practice English whenever there is a chance in class. & 2.07 & .75 & Positive \\
\hline 13- I hope to make friends with native English speakers. & 2.31 & .87 & Positive \\
\hline 14- I hope to write English to develop relationships around world. & 2.31 & .79 & Positive \\
\hline 15- I need English because it helps me when I travel abroad. & 1.83 & .86 & Positive \\
\hline 16- Writing in English is a hard task & 1.87 & .72 & Positive \\
\hline 17- I like English class because it helps me to learn more. & 1.75 & .75 & Positive \\
\hline 18- I don’t enjoy memorizing new vocabulary. & 2.08 & .87 & Positive \\
\hline 19- I prefer to join the English club at my school. & 1.63 & .77 & Negative \\
\hline 20- I find learning English boring. & 2.09 & .74 & Positive \\
\hline 21- I feel happy when English class is canceled. & 1.92 & .79 & Positive \\
\hline 22- I am interested when doing writing activities. & 1.79 & .73 & Positive \\
\hline 23- I enjoy taking part in cooperative tasks. & 1.98 & .80 & Positive \\
\hline $\begin{array}{l}\text { 24- Learning English helps me to communicate with English } \\
\text { speakers. }\end{array}$ & 2.28 & .75 & Positive \\
\hline Overall mean & 2.04 & .25 & Positive \\
\hline
\end{tabular}

The result of the study indicated that the Saudi learners' overall attitude toward English language learning is positive $(\mathrm{M}=2.04>1.66$ and $\mathrm{SD}=0.25)$.

Table 1. shows the three uppermost means of the learners' attitude toward English learning. First, the item "Mastering English will help me get a suitable job in the future" has the highest means $(\mathrm{M}=2.51>1.66$ and SD $=0.62$ ) among all the language attitude items. This shows that majority of the learners have a positive attitude toward English learning, and they believe that learning English could help them to find a suitable job. Second, the item "I always practice English outside school" is the second highest item $(\mathrm{M}=2.44>1.66$ and $\mathrm{SD}=0.85)$. This indicates that the learners are willing to learn English outside of school to develop their performance. Finally, the item "I feel proud when I speak in English" is third highest of the attitude items $(\mathrm{M}=2.40>1.66$ and $\mathrm{SD}=0.76$ ). This mean that learners appreciate the ability to speak English. 


\section{5- Discussion and conclusion}

The purpose of this study was to examine high school learners' attitudes toward English language learning in Saudi Arabia. Whereas several studies have examined students' attitude toward English language learning in universities, limited studies related to high school learners in Saudi Arabia have been done. In general, this study found that Saudi learners' attitude toward English language learning was positive. A possible explanation is that learners value the importance of learning English in their present and future career, so they try to develop their communication abilities.

The result of this study is consistent with previous studies such as Alkaff (2013) and Ibnian (2017), which found that English is important for learners' futures, especially when they travel abroad, and it could provide them with better job opportunities. Khalid (2019) pointed out that learners had a positive attitude toward English learning, and they agreed that proficiency in English is advantageous and helped them to succeed in their professional life. This is in contrast with the findings of Khan (2016) and Ahmed (2015), where the attitude toward English learning was negative. Nonetheless, this is the first study that has examined the attitudes of high school learners in Saudi Arabia, so this finding needs to be confirmed. In this respect, several studies have suggested that a negative attitude affects FL skills performance (e.g., Dewaele \&Dewaele, 2018; Ahmed, 2015), because language mastery provides learners with opportunities to acquire language skills. The current study suggests that the interests and agency of learners need to be taken into consideration.

However, our study had several limitations. First, the sample of the study was only from Taif city, so future studies are needed to include samples from a greater geographical area in Saudi Arabia. We remain cautious of generalizing our finding because of the small sample size. Second, all the participants were male. Future studies should include female learners. Finally, the attitudes were measured using a questionnaire which depended on learners' beliefs, not on real interactions in the classroom. Other measures, such as interviews, are complementary to questionnaires in attitude studies.

In conclusion, this study has investigated the attitudes of foreign language learners using a descriptive method. The result indicates that English language learning at high school requires a positive attitude to practice and develop language skills. This study has some applications, such as that teachers should create a pleasant atmosphere in the classroom that boosts learners' positive attitudes toward English and as a result, they can better develop their English language skills. In addition, teachers should design experiences that match the learners' interests. Future research should examine the attitude of learners toward learning specific skills such as writing or reading stories and carry out more studies with more participants. Moreover, other research using qualitative methods is needed to identify the attitudes of learners toward English learning and its challenges.

\section{References}

Abidin. M., Pour-Mohammadi. M, Alzwari. H ( 2012). EFL students' attitudes towards learning English language: The case of Libyan Secondary school students. Asian Social Science, 8(2): 119-134. https://doi.org/10.5539/ass.v8n2p119

Ahmed, S. (2015). Attitudes towards English Language Learning among EFL Learners at UMSKAL. Journal of education and practice, 6(18), 6-16.

Al Samadani, H. A., \& Ibnian, S. (2015). The relationship between Saudi EFL students' attitudes towards learning English and their academic achievement. International Journal of Education and Social Science, 2(1), 92-102.

Alkaff, A. A. (2013). Students' Attitudes and Perceptions towards Learning English. Arab World English Journal, $4(2)$.

Alnoursi, O. (2013). Attitude towards Learning English: The case of the UAE Technological High School. Educational Research (4) 1, 21-30

Al-Sobhi, B., Md Rashid, S., \& Abdullah, A. N. (2018). Arab ESL secondary school students' attitude toward English spelling and writing. SAGE Open, 8(1), https://doi.org/10.1177/2158244018763477.

Aouachria, S. S. (2015). Attitudes of Middle School Students towards Learning English as a Second Foreign Language in Algeria. Journal of Educational \& Psychological Sciences, 16(01).

Bohner, G., \& Dickel, N. (2011). Attitudes and attitude change. Annual review of psychology, 62, 391-417. https://doi.org/10.1146/annurev-psych-122216-011911

Brown, H. D. (2007). Principles of language learning and teaching (5th ed). New York: Longman.

Cherciov, M. (2013). Investigating the impact of attitude on first language attrition and second language acquisition from a Dynamic Systems Theory perspective. International Journal of Bilingualism, 17(6), 716733. https://doi.org/10.1177/1367006912454622

Dewaele, J. M., \& Dewaele, L. (2018). Learner-internal and learner-external predictors of willingness to communicate in the FL classroom. Journal of the European Second Language Association. 2(1), 24-37, DOI: https://doi.org/10.22599/jesla.37

Dittmar, N. (1976). Sociolinguistics: A critical survey of theory and application. London, UK: Edward Arnold. 
http://dx.doi.org/10.12785/JEPS/160116

Ibnian, S. S. (2017). Attitudes of Public and Private Schools' Students towards Learning EFL. International Journal of Education. 9(2), 70-83

Jaliyya, F. G., \& Idrus, F. (2017). EFL Students' Attitudes and Perception Towards English Language Learning and Their English Language Proficiency: a Study From Assa'adah Islamic Boarding School, Indonesia. Journal of Education and Learning, 11(3), 219-228. http://dx.doi.org/10.11591/edulearn.v11i3.4621

Khalid, A. (2016). A study of the attitudes and motivational orientations of Pakistani learners toward the learning of English as a second language. SAGE Open, 6(3), https://doi.org/10.1177/2158244016665887.

McKenzie, R. M. (2010). The social psychology of English as a global language: Attitudes, awareness and identity in the Japanese context. Springer Science and Business Media.

McLeod, S. A. (2018). Attitudes and behavior. Retrieved from https://www.simplypsychology.org/attitudes.html

Oskamp, S., \& Schultz, P. W. (2005). Attitudes and opinions. Psychology Press.

Tsunemoto, A., \& McDonough, K. (2020). Exploring Japanese EFL Learners' Attitudes Toward English Pronunciation and its Relationship to Perceived Accentedness. Language and Speech. (1). https://doi.org/10.1177\%2F0023830919900372.

Wilkins, J. L. (2010). Elementary school teachers' attitudes toward different subjects. The Teacher Educator, 45(1), 23-36. https://doi.org/10.1080/08878730903386856

Zulkefly, F., \& Razali, A. B. (2019). Malaysian Rural Secondary School Students' Attitudes towards Learning English as a Second Language. International Journal of Instruction, 12(1), 1141-1156. https://doi.org/10.29333/iji.2019.12173a 